\title{
PENERAPAN PENDIDIKAN AGAMA YPK.KM SMA KATOLIK ST. THOMAS AQUINO MANADO
}

\author{
The Application of Religious Education at YPK. KM \\ SMA Katolik ST. Thomas Aquino Manado
}

\author{
Abdul Rahman Arsyad \\ Balai Penelitian Dan Pengembangan Agama Makassar \\ Jl. A. P. Petta Rani No. 72 Makassar \\ E-mail: rahmanantang70@gmail.com
}

Naskah diterima tanggal 9 Februari 2015. Naskah direvisi tanggal 9 Maret 2015. Naskah disetujui tanggal 22 Mei 2015

\begin{abstract}
Abstrak
Penelitian ini bertujuan untuk mengungkap pelaksanaan dan inovasi pembelajaran pendidikan agama serta factor pendukung dan penghambat pembelajaran pendidikan agama pada YPK.KM SMA Katolik St. Thomas Aquino Manado dengan menggunakan metode Kualitatif. Hasil penelitian menunjukkan bahwa penerapan pembelajaran pendidikan agama dan pendidikan keagamaan diimplementasikan secara integrasi yang dilaksanakan pada dua tempat yaitu: sekolah (kelas) dan gereja. Dimana, sebelum dan sesudah pembelajaran dilakukan ibadah (misa bersama), berdoa dengan menggunakan dua bahasa Indonesia dan inggris. Sedangkan kurikulum diatur lewat KWI, silabus yang digunakan mengacu/berpedoman pada Diknas dan Kemenag serta yayasan yang di kombainkan kedalam RPP. Sumber reverensi adalah Kementerian Agama dan KWI, sehingga peserta didik yang beragama lain menerima materi hanya sebatas ranah kognitif dengan penilaian secara pluralitas. Faktor pendukung; merupakan sekolah unggulan, latar belakang pendidik adalah rata-rata sarjana, pihak sekolah dan yayasan membangun komunikasi dan koordinasi secara berkesinambungan dalam mewujudkan kerukunan dan keharmonisan sesama warga sekolah, sedangkan Faktor penghambat; terbatasnya guru agama, keterbatasan dalam berimvrofisasi, dan proses pembelajaran mengacu pada visi misi dan tujuan organisasi sekolah, serta orang tua dan masyarakat menyepakati aturan pihak sekolah dan yayasan.
\end{abstract}

Kata Kunci: inovasi, pendidikan, agama

\section{Abstract}

The study aims to discover the implementation and the innovation of religious education learning and factors supporting and hindering the religious education learning at YPK.KM Catholic Senior High School St. Thomas Aquino Manado by using qualitative methods. The results showed that the application of religious education learning was implemented in integrated way carried out in two places: the school (class) and the church. In which, worship and praying (together) using two languages, Indonesian and English were performed before and after learning process. The curriculum is regulated by Bishops' Conference Indonesia (Konfrensi Waligereja Indonesia) and the syllabus is guided by the Ministry of Education and the Ministry of Religious Affairs as well the foundations combined into lesson plans. The sources of references are taken from the Ministry of Religious Affairs and Bishops' Conference Indonesia, so the students from other religions obtained materials only in cognitive domain with plurality assessment. The supporting factors; it as an excellent school, the educational backgrounds of teachers are average undergraduate, the school and the foundation build communication and coordination continuously in achieving harmony for the people at the school. On the other hand, the hindering factors; the religion teachers are still few, the improvisations are still limited, and the learning process refers to visions, missions, and the goals of the school organization, and parents and the community agree with the rules of the school and the foundation.

Keywords: innovation, education, religion 


\section{PENDAHULUAN}

$\mathrm{P}$ enelitian ini dilatarbelakangi dari hasil penelitian Badan Litbang Dan Diklat Kementerian Agama Penyelenggaraan Pendidikan Keagamaan Kristen, Katolik, Hindu, Budha, dan Konghuchu pada 33 provinsi yang melahirkan rekomendasi pentingnya sosialisasi PP 55 Tahun 2007. Kemudian penelitian Listia, Laode Arham dan Lian Gogali mengenai Problematika Pendidikan Agama pada sekolah SD, SMP, dan SMA Jogyakarta. Menggambarkan pendidikan agama yang dilaksanakan oleh yayasan keagamaan di antaranya perlunya dilakukan pembeharuan sistem pendidikan agama, khususnya dalam segi materi dan metode pembelajaran, pemberdayaan guru agar mampu berkreatif dan berinovasi dalam memfasilitasi perkembangan kemampuan siswa terhadap iman dan kepercayaan. Dari hasil penelitian, yang merupakan hal pokok adalah pelaksanaan PP 55 Tahun 2007, keunikan sistem pembelajaran agama pada sekolah binaan yayasan, dan system pembelajaran agama yang mengedepankan nilai-nilai pluralistik.

Terkait dengan pendidikan agama bagi peserta didik, maka pemerintah telah menetapkan peraturan bahwa setiap peserta didik pada satuan pendidikan disemua jalur, jenjang dan jenis pendidikan berhak mendapat pendidikan agama sesuai agama yang dianutnya dan diajar oleh pendidik yang seagama berdasarkan Peraturan Pemerintah Nomor 55 Tahun 2007 Pasal 4 Ayat 2.

Jika kita ingin pendidikan agama di sekolah benar-benar fungsional dan kontekstual dengan masalah kehidupan bermasyarakat, berbangsa, dan bernegara. Maka, aspek-aspek pendidikan agama di sekolah harus secara skala prioritas dan garapan materi sebagai berikut: pertama pendidikan agama sebaiknya mengutamakan dimensi konsekuensi keberagamaan, kedua dimensi eksperiensial digarap dengan upaya-upaya menghadirkan Tuhan dalam kesadaran siswa, ketiga pengolahan dimensi ideologis dilakukan dengan tetap mengedepankan perlunya sikap kerendahan hati dan kelapangan jiwa, keempat pengajaran dan pelatihan tata cara ritusritus agama haruslah dilakukan sambil menekankan penyadaran siswa bahwa ritualitas lebih merupakan upaya peneguhan komitmen keber-Tuhanan seseorang, penjernihan rohani, dan penghadiran Tuhan dalam jiwa, sehingga efektivitasnya haruslah berupa perilaku hidup baik, kelima pengajaran dimensi intelektual di samping menyangkut hal- hal seputar sejarah keagamaan, isi kitab suci dan semacamnya, penting pula mengetengahkan diskursus tentang bagaimana nilai-nilai luhur agamawi dapat diejawantahkan dalam praksis kehidupan nyata di alam sosial Indonesia masa kini dan juga antisipatif terhadap masa depan. Dengan demikian, intelektualisme keagamaan menjadi kontekstual dengan situasi zaman (Wahab, 2010: 26-27).

Kemudian dengan pendidik pendidikan agama, pemerintah juga telah menetapkan aturan bahwa: (1) Pendidik pendidikan agama pada satuan pendidikan agama di satuan pendidikan yang diselenggarakan oleh pemerintah atau pemerintah daerah disediakan oleh pemerintah atau pemerintah daerah sesuai dengan kewenangan masing-masing berdasarkan ketentuan Peraturan Perundangundangan. (2) Pendidik pendidikan agama pada satuan pendidikan yang diselenggarakan oleh masyarakat disediakan oleh satuan pendidikan yang bersangkutan (PP Nomor 55 Tahun 2007 Tentang Pendidikan Agama dan Pendidikan Keagamaan, Bab 11, Pasal 6, ayat 1 dan 2).

Untuk mengetahui bagaimana inovasi pembelajaran pendidikan agama pada sekolah SMA Katolik St. Thomas Aquino Manado, maka perlu ada kajian lewat penelitian. Inovasi yang akan dikaji lebih mendalam yaitu: pada aspek proses pembelajaran pendidikan agama, konsep kurikulum yang dikembangkan dalam pembelajaran, dan out put yang diharapkan sekolah dan yayasan.

Berdasarkan latar belakang masalah penelitian di atas, maka fokus penelitian adalah sebagai berikut: Bagaimana pelaksanaan dan inovasi pembelajaran pendidikan agama yang dikembangkan YPK. KM SMA Katolik St. Thomas Aquino Manado? Faktor pendukung dan penghambat dalam inovasi pembelajaran pendidikan agama di SMA Katolik St. Thomas Aquino Manado?. Tujuan Penelitian. Untuk mengetahui, menganalisa, menyimpulkan dan merekomend-asikan tentang pelaksanaan dan inovasi pembelajaran pendidikan agama, serta faktor pendukung dan penghambat dalam pembelajaran pendidikan agama yang dikembangkan sekolah SMA Katolik St. Thomas Aquino Manado.

\section{Tinjauan Pustaka}

Pengertian Inovasi (Ancok, 2012: 34) Menurut Rosabeth Moss Kanter (1986), inovasi adalah sebuah hasil karya pemikiran baru yang diterapkan dalam kehidupan manusia. Sedangkan menurut Amabile \& Conti (1999) inovasi adalah Implementasi dan pemikiran baru oleh individu maupun organisasi. 
Menurut Lena Allita dan Lina Anatan, (2009: 37) secara umum inovasi memiliki makna proses megadopsi sesuatu yang baru oleh siapapun yang memiliki adopsi, dan sebagai proses menciptakan produk baru (Woodman et.al. 1993 dan Gilbert, 2003). Inovasi merupakan suatu konsep multidimensional yang terdiri dari empat dimensi yaitu: Orientasi kepemimpinan perusahaan terhadap inovasi (Maidique and Patch, 1988), type inovasi yang dilakukan (Betz, 1987), sumber inovasi (Mansfield, 1988), investasi yang dibutuhkan dalam inovasi (Thomson and Ewer, 1989). Inovasi pada prinsipnya dapat terjadi pada berbagai aspek, misalnya dalam dunia pendidikan inovasi strategi pembelajaran, inovasi pola pikir pendidik dan tenaga kependidikan, inovasi model pembelajaran dan inovasi pelayaanan pendidikan. Inovasi tersebut bermuara pada peningkatan kualitas sekolah, terutama dalam memberikan jasa pendidikan.

Sementara Ancok, (2012: 36-40) secara umum menggambarkan ada delapan jenis inovasi di antaranya: inovasi proses, inovasi metode, inovasi struktur organisasi, inovasi dalam hubungan, inovasi strategi, inovasi pola pikir, inovasi produk, dan inovasi pelayanan. Jenis inovasi ini berjalan secara integratif dan saling terkait.

Tiap pendidik dapat melakukan sebuah pengembangan kurikulum sesuai dengan kebutuhan, visi dan misi sekolah, beberapa hal yang menjadi prinsip pengembangan kurikulum adalah : (1) berorientasi pada tujuan, (2) relevansi (kesesuaian), (3) efesiensi dan efektifitas, (4) fleksibilitas, (5) berkesinambungan, (6) keseimbangan, (7) keterpaduan, (8) mutu (Oemar Hamalik, 2013: 3032).

Dalam pengembangan organisasi pembelajar maka paradigma organisasi pembelajar erat kaitannya dengan beberapa faktor yang mempengaruhi, yakni: Kepemimpinan, struktur berbasis tim, pemberdayaan staf/karyawan, keterbukaan informasi, strategi partisipatif, dan budaya adaptif (Iskandar Agung, 2012: 54).

Proses pembelajaran di sekolah, masingmasing siswa memiliki ketertarikan yang berbeda, orientasi kepribadian yang berbeda serta latar belakang lainnya, lingkungan sekolah memberikan pengaruh yang besar terhadap berlangsungnya interaksi psikologi sosial pada masing-masing individu, inilah yang membuat perbedaan (Abu Ahmadi, 2002: 296).

Pembelajaran bertujuan untuk mencerdaskan bangsa dan pencerahan umat sehingga nantinya akan mencetak anak-anak bangsa sebagai kader yang baik, berotak cemerlang, penuh dengan daya kreatif, inovasi dan bertingkah laku yang sopan, santun, dan dilaksanakan dengan penuh perhatian. Pembelajaran yang dimaksud adalah model pembelajaran yang tidak menakutkan, membosankan, mengaktifkan siswa dengan mendapatkan pengalaman belajar dari berbagai sumber (Nur Zazin, 2011: 127).

Dijelaskan dalam Bab I Ketentuan Umum Peraturan Pemerintah Republik Indonesia Nomor 55 Tahun 2007 tentang Pendidikan Agama dan Pendidikan Keagamaan bahwa pendidikan agama adalah pendidikan yang memberikan pengetahuan dan membentuk sikap, dilaksanakan sekurangkurangnya melalui mata pelajaran/kuliah pada semua jalur, jenjang, dan jenis pendidikan.

\section{METODE PENELITIAN}

Metode penelitian ini menggunkan metode kombinasi yang menggabungkan metode kualitatif sebagai data primer dan kuantitatif sebagai data sekunder (Sugiono, 2013: 537-541).

Data yang sifatnyakualitatifdiperoleh darihasil wawancara dan studi dokumen dianalisis dengan teknik analisis kualitatif model interaktif yang secara simultan terdiri atas tahapan, diantaranya: pengumpulan data, pengklasifikasiaan data, penyajian data, dan penarikan simpulan/verifikasi. Sedangkan data kuantitatif menggunakan analisa tingkat kepentingan dan harapan (importanceperformance analysis) sebagaimana yang dijelaskan secara rinci oleh (Supranto, 2001: 239-242).

Sasaran penelitian adalah YPK.KM SMA Katolik St. Thomas Aquino Manado. Teknik pengumpulan data yang digunakan dalam penelitian adalah wawancara, observasi, telaah dokumen, dan angket. Data yang sifatnya kualitatif diperoleh dari hasil wawancara dan studi dokumen dianalisis dengan teknik analisis kualitatif model interaktif yang secara stimultan terdiri atas tahapan, di antaranya: pengumpulan data, pengklasifikasiaan data, penyajian data, dan penarikan simpulan/ verifikasi.

\section{PEMBAHASAN \\ Profil Sekolah}

Lembaga pendidikan sebelum SMA Katolik St. Thomas Aquino Manado adalah SMEA yang dipimpin oleh Drs. J.D. Paat (kasek) tahun 1951 s/d 1981. Kemudian pada tahun 1983-sekarang SMA Katolik St.Thomas Aquino yang beralamat di Jl. Gereja Santu Josep No. 17A, Kecamatan Sario 
Kota Manado. Yang diselenggarakan oleh Yayasan Pendidikan Katolik Keuskupan Manado dengan luas areal $7.976 \mathrm{~m}^{2}$, atas nama Gereja Santu Joseph Pekerja Manado dengan status hak milik, telah dipimpin lima orang kepala sekolah, diantaranya: Drs. J. D. Paat (1983), Drs. D. D. Rewah (19831993), M. Kaka, BA (1993-1996), Drs. Z. Kayobe (1996-2007), sedangkan tahun 2007-sekarang Dra. Y. D. Wantania, MM.

Untuk jumlah jam pelajaran dibutuhkan dalam seminggu 42 jam yang diselenggarakan mulai 07.15-13.45. Sedangkan jumlah guru/pegawai 26 orang di antaranya: guru PNS 10, guru tetap yayasan 6 orang, guru tidak tetap 4 orang, pegawai tetap 2 orang, satpam 1 orang dan Katakese 3 orang. Sedangkan guru agama 2 orang (PNS dan yayasan).

Kondisi siswa secara kuantitas berjumlah 236 (pria 126 dan wanita 110) dari 8 kelas dan 2 jurusan (IPA dan IPS) diantaranya : Kelas X 1-3 (103), Kelas XI-2 (42), Kelas XII-3 (91). Kondisi sarana dan prasarana, ruang kelas 10, ruang kasek 1 , ruang guru 1 , perpustakaan 1 , ruang pelayanan administrasi 1 , kantin, 1, ruang UKS dan OSIS 1, laboratorium 1, lapangan olah raga $1, \mathrm{KM} / \mathrm{WC} 8$, dengan kondisi baik.

Visi, terbentuknya siswa dan siswi SMA Katolik St. Thomas Aquino Manado yang berakhlak mulia, berkualitas, kokoh iman serta dapat mencerminkan hidup Kristiani dengan penuh kasih. Misi, Menanamkan semangat cinta kasih sebagai wujud sikap hidup iman katolik; meningkatkan kompetensi keagamaan yang meliputi pengetahuan, sikap kepribadian, kejujuran, ketaqwaan terhadap Tuhan Yang Maha Esa; melaksanakan pembelajaran dan pembimbingan secara efektif sehingga siswa berkembang secara optimal sesuai dengan potensi yang dimiliki; mengembangkan bakat minat potensi siswa sebagai salah satu modal kehidupan dikemudian hari. Tujuan sekolah mampu mempertahankan ciri khas sebagai sekolah katolik; mampu menghadapi dan menjawab tantangan global; mampu menamatkan siswa yang dapat melanjutkan studi kejenjang yang lebih tinggi dengan predikat baik; mampu memiliki prestasi yang unggul, baik dalam bidang akademik dan non-akademik; mampu memiliki perilaku yang mencermin karakter bangsa.

\section{Lembaga Pendidikan}

Kondisi lembaga pendidikan di Manado, N/S yang tersebar di Kecamatan Malalayang, Sario, Wanea, Wenang, Tikala, Mapanget, Singkil, Tuminting, Bunaken, yaitu : SMA 46 (guru 726 dan siswa 10.831), SMK 33 (guru 505 dan siswa 9.329), dan MA 5 (siswa 1.117). Perbandingan antara usia 15-19 tahun dengan jumlah siswa pada jenjang tingkat atas, terdapat $8,65 \%$ siswa yang mengenyam pendidikan dari jumlah penduduk di Kota Manado. Yayasan Katolik yang tersebar dari $15 \mathrm{Kab} /$ Kota di Provinsi Sulawesi Utara, masing-masing memiliki lembaga pendidikan baik tingkat dasar, menengah maupun perguruan tinggi, Yayasan Katolik Provinsi Sulawesi Utara yaitu: Yayasan Keuskupan Manado $(\mathrm{TK}=81, \mathrm{SD}=136, \mathrm{SMP}=38$, $\mathrm{SMA}=13$, dan $\mathrm{SMK}=2)$, Yayasan Maria Yosef $(\mathrm{TK}=$ $2, \mathrm{SD}=6, \mathrm{SMP}=2, \mathrm{SMA}=1$, dan $\mathrm{SMK}=1$ ), Yayasan Frater Andreas $(\mathrm{TK}=2, \mathrm{SD}=4, \mathrm{SMP}=2$, dan $\mathrm{SMA}=$ 1), Yayasan Orsulin $(S M P=1$ dan $S M A=2$, Yayasan Yamaru (PTS= 1). dan Yayasan Pendidikan Lakon $(\mathrm{SMP}=1$ dan $\mathrm{SMA}=1)$.

Adapun gambaran YPK. KM SMA Katolik St. Thomas Aquino, secara kuantitas yaitu, sebagai berikut: jumlah guru secara keseluruhan 20, pegawai 6, jumlah siswa 236 Kelas X 103, Kelas XI 89, Kelas XII 44 (pria 142 dan wanita 94) sedangkan siswa berdasarkan agama, yaitu: Islam 3 orang, Katolik 89 orang, Protestan 143, dan Hindu 1 orang, untuk jumlah guru agama 2 (PNS dan yayasan).

\section{Kondisi Pemeluk Agama Dan Rumah Ibadah}

Kehidupan beragama merupakan salah satu wujud keragaman di Kota Manado dan kerukunan beragama serta pendidikan agama dan keagamaan dapat dikatakan telah terbina dengan baik. Ini terlihat adanya singkronisasi antara jumlah rumah ibadah dengan pemeluk agama.

Adapun jumlah penduduk berdasarkan pemeluk agama dan rumah ibadah di Kota Manado, yaitu : Penduduk 415.114 (pria 204.502 dan wanita 210.612), Pemeluk Agama Islam 128.483 (Masjid 187 dan Mushola 30), Protestan 254.912 (Gereja 523), Katolik 20.603 (Gereja 21), Hindu 692 (Pura 4), Budha 2.244 (Vihara 20), dan Konghuchu 0. Berdasarkan informasi BPS Kota Manado, menunjukkan bahwa jumlah penduduk adalah mayoritas memeluk agama Kristen.

\section{Peran Yayasan Dan Kepala Sekolah}

Pendidikan Agama Katolik merupakan suatu usaha yang dilakukan agar siswa memiliki kemampuan untuk membangun hidup yang semakin beriman Kristiani dan bertaqwa terhadap Tuhan Yang Maha Esa sesuai dengan ajaran Gereja Katolik. Membangun hidup beriman Kristiani berarti membangun kesetiaan pada Injil Yesus 
Kristus, yang memiliki keprihatinan tunggal, yakni Kerajaan Allah. Kerajaan Allah merupakan situasi dan peristiwa penyelamatan: situasi dan perjuangan untuk perdamaian dan keadilan, kebahagiaan dan kesejahteraan, persaudaraan dan kesetiaan serta kelestarian lingkungan hidup, yang dirindukan oleh setiap orang dari pelbagai agama dan kepercayaan.

Peran yayasan adalah memberikan bimbingan dan pembinaan, serta memberikan kontribusi terhadap semua aspek komponen pendidikan, baik penerimaan siswa, kurikulum, pendidik/tenaga pendidik, sarana dan prasarana, serta operasional pengelolaan pendidikan pada semua jenjang satuan pendidikan dibawah binaan yayasan pendidikan katolik keuskupan.

Kurikulum yang digunakan dalam proses pembelajaran pendidikan agama diatur lewat Komisi Kateketi Keuskupan KWI, dengan memiliki tujuan untuk menjaga dan memelihara ajaranajaran gereja. Sehingga para orang tua siswa yang ingin menyekolahkan anaknya harus mengikuti aturan main yayasan, dengan membuat dan menadatangani pernyataan yang dibuat oleh pihak sekolah "Hanya mengajarkan pengetahuan Agama Katolik kepada semua siswa sesuai ciri khas sekolah Katolik" (St. Bernadette Mokorimban, Jmj. Paroki Pendik).

Perekrutan pendidik dan tenaga kependidikan (PNS dan non-PNS) adalah wewenang yayasan. Begitupun dengan persiapan ujian, para guru mengikuti sosialisasi yang dilaksanakan oleh pihak yayasan dalam bentuk bimbingan dan pembinaan, agar pelaksanaan ujian berjalan dengan baik sehingga harapan orang tua, sekolah, dan yayasan dapat terwujud.

Kontribusi yayasan masih dalam tahap administratif (sertifikasi), sedangkan anggaran bersumber dari pemerintah dan masyarakat. Untuk fasilitas pembelajaran pendidikan agama dan pendidikan keagamaan dilaksanakan dilingkungan sekolah dan gereja. Bagi siswa kelas X, XI, dan XII mengikuti kegiatan ekstrakurikuler Emaus (praktek keagamaan) yaitu: pembinaan karakter mulia, sedangkan untuk kelas XII diharuskan untuk mengikuti kegiatan Retret (pembinaan iman dan keterampilan) disaat akhir sekolah.

Yayasan dalam hal ini, memiliki tanggung jawab dalam melayani umat dan lembaga pendidikan katolik, berdasarkan paroki (area). Sehingga umat dan lembaga pendidikan dapat terlayani sesuai dengan harapan. Adapun struktur yang Yayasan Pendidikan Katolik Keuskupan Manado (YPK.KM) yaitu:

Pendiri : Mgr. Josep Suwatan, MSc

Pembina : Pastor Fradikus Stefanus Tawaluyan. Pr (Ketua)

Bapak Ferry Doringin (Anggota)

Pengurus : Pastor Feki Singel. Pr (Pimpinan)

Sr. Bernadette Mokorimban, Jmj

(Sekretaris)

Pastor Yasen Dianomo. Pr (Bendahara)

Lusia Sutrisno, Angela Isty, Alfrida

Kumayas, Stevi Enas (Karyawan)

Pengawas : Pastor Lexsia Nangoy $\operatorname{Pr}$ (Ketua), Bapak Drs. Alex Ch. Pali (Anggota)

Lembaga pendidikan formal TK, SD, SMP,

SMA/SMK, dan PTS masing-masing memiliki perwalian yang dipimpin oleh pastor dan beberapa staf, guna memudahkan koordinasi dan komunikasi. Sedangkan tugas dan fungsi yayasan adalah memonitoring/mengawasi dan mengevaluasi lembaga pendidikan formal secara menyeluruh.

Sedangkan peran kepala sekolah sangat menentukan kemana dan akan menjadi apa organisasi yang dipimpinnya. Sehingga dengan kehadiran seorang pemimpin akan membuat organisasi menjadi satu kesatuan yang memiliki kekuatan untuk berkembang dan tumbuh menjadi besar

Peningkatan mutu pendidikan Pendidikan Agama Katolik adalah usaha yang dilakukan secara terencana dan berkesinambungan dalam rangka mengembangkan kemampuan peserta didik untuk memperteguh iman dan ketaqwaan terhadap Tuhan Yang Maha Esa sesuai dengan ajaran Gereja Katolik, dengan tetap memperhatikan peghormatan terhadap agama lain didalam hubungan kerukunan antar umat beragama dalam masyarakat untuk mewujudkan persatuan nasional.

Dalam kurikulum pembelajaran pendidikan agama diatur lewat Komisi Kateketi Keuskupan KWI. Namun, dalam evaluasi melibatkan berbagai alat: dari tes sampai non-tes. Tetapi alat evaluasi yang digunakan adalah tes, itupun sifatnya hapalan. Maka hasil belajar peseta didik lebih banyak bersifat kognitif.

Penerapan pendidikan agama dilakukan secara integrasi kepada semua peserta didik, karena para orang tua siswa sudah mengetahui dan menyetujui aturan main di SMA Katolik St. Thomas Aquino, dalam pembelajaran pendidikan agama 
(wawancara, Yulien D. Wantania. Kepsek).

Penanaman nilai yang diterapkan pihak sekolah dalam bentuk pembinaan moral, yaitu: membina para pendidik dan tenaga kependidikan tentang hal-hal yang berkaitan dengan ajaran baik buruk mengenai suatu perbuatan, sikap, dan kewajiban sesuai dengan tugas masing-masing, begitupun dengan pembinaan lainnya, serta tak henti-hentinya kepala sekolah memberikan nasehat kepada semua warga sekolah dalam mewujudkan penanaman nilai pada lingkungan sekolah.

Pihak sekolah mengedepankan suasana yang rukun, dengan melakukan kegiatan pendampingan bagi semua peserta didik, sehingga nampak adanya sinergisitas antara pihak sekolah dan orang tua siswa dalam mengembangkan pendidikan multi relegius serta menciptakan hubungan yang harmonis.

\section{Pengembangan Inovasi Komponen Pendidikan Agama}

Pendidikan agama di sekolah teredukasi menjadi pengajaran agama, yang cenderung menekankan pada penguatan aspek pengetahuan (ranah kognitif) melalui penghafalan dan sejenisnya. Dalam bunga rampai pendidikan Islam (Atho Mudzhar, 2009:107).

Satu inovasi yang menarik mengiringi perubahan paradigma tersebut adalah ditemukan dan di terapkannya model Pembelajaran InovatifProgresif (praktik belajar). Praktik belajar diartikan sebagai suatu inovasi pembelajaran yang dirancang untuk membantu peserta didik memahami teori/ konsep-konsep melalui pengalaman belajar praktikempiris. Oleh karena dalam model pembelajara ini hasil akhirnya adalah assessment (penilaian) yang bersifat komperhensif, baik dari segi proses maupun produk pada semua aspek pembelajaran, yaitu aspek kognitif, afektif, maupun psikomotorik.

Ada beberapa masalah yang dihadapi dunia pendidikan sekarang ini, walaupun telah diberlakukan otonomi daerah sebagai konsekuensi penerapan Undang-Undang Nomor 22 Tahun 2009, permasalahan itu tampaknya akan tetap ada, bahkan akan semakin kompleks. Masalah tersebut adalah masalah relevansi kualitas, efektivitas dan efesiensi, daya tamping sekolah yang terbatas (Wina Sanjaya. 2009:318).

Konsep pendidikan dalam pelaksanaan pendidikan agama pada sekolah merupakan konsep yang lebih tepat dari konsep pengajaran. Pendidikan adalah segala usaha orang dewasa (tenaga pendidik) untuk memimpin perkembangan jasmani dan rohaninya ke arah kedewasaan agar berguna bagi dirinya sendiri dan bagi masyarakat (Ngalim Purwanto, 2000:17).

Dalam pengembangan silabus harus memiliki beberapa prinsip, agar pelaksanaan pembelajaran dapat berjalan dengan efektif dan efesien, yaitu: Ilmiah (materi dan kegiatan yang menjadi muatan dalam silabus harus dapat dipertanggungjawabkan secara keilmuan); relevan (tingkat kesukaran dan urutan penyajian materi dalam silabus sesuai dengan tingkat perkembangan fisik); sistematis (komponen silabus saling berhubungan secara fungsional dalam mencapai kompetensi); Konsisten (adanya hubungan yang konsisten antara kompetensi dasar, materi pokok, pengalaman dan sumber belajar, serta system penilaian); memadai (cakupan indikator materi pokok, sumber dan pengalaman belajar serta system penilaian cukup untuk menunjang $\mathrm{KD}$ ); aktual dan Kontekstual (sistem penilaian memperhatikan perkembangan ilmu, teknologi dan seni muktahir dalam kehidupan nyata, serta peristiwa yang terjadi); fleksibel (seluruh komponen silabus dapat mengakomodasi keragaman peserta didik, pendidik, serta dinamika perubahan yang terjadi di sekolah dan tuntutan masyarakat); dan Menyeluruh (komponen silabus mencakup keseluruhan ranah kognitif, afektif, psikomotorik) (Trianto, 2010:201-202).

\section{Inovasi Guru Agama}

Clayton M \& Michael, (2006:41-43) dalam melakukan sebuah inovasi ada tiga unsur yang menjadi tantangan, yaitu: pertama tingkat kecepatan perkembangan teknologi, kedua rentang performa hasil inovasi yang dapat dimanfaatkan, dan ketiga rentang pemahaman inovasi yang diterapkan.

Secara implementatif dalam pembelajaran inovasi harus diwujudkan dalam desain pembelajaran, desain adalah proses untuk menentukan kondisi belajar, sedangkan tujuan dari desain adalah untuk menciptakan strategi serta produk pada tingkat makro seperti program dan kurikulum sedangkan pada tingkat mikro seperti pelajaran dan modul. Dalam inovasi pendidikan dan pembelajaran maka desain dipengaruhi empat hal yaitu: desain sistem pembelajaran; desain pesan; dan Strategi pembelajaran; serta karakteristik pembelajaran (Deni Darmawan, 2012:4).

Menurut Ibu Ketsia (guru agama). Pelaksanaan 
pembelajaran pendidikan agama yang diterapkan pada satuan pendidikan formal, tidak terlepas dari komponen dan materi pendidikan agama Katolik. Namun, dalam penentuan kriteria ketuntasan minimal per SK dan KD saling terkait.

Proses pembelajaran pendidikan agama dilaksanakan secara integrasi terhadap semua siswa (kelas X, XI, dan XII) yang multi religius, sehingga keharusan bagi peserta didik untuk mengikuti prosesi pembelajaran pendidikan agama dan pendidikan keagamaan yang telah disepakati.

Salah satu contoh kriteria ketuntasan minimal mata pelajaran (KKM), yaitu: SK (memahami makna firman Allah, ajaran Yesus dan ajaran Gereja dalam mengembangkan kehidupan bersama sesuai dengan kehendak Allah, sehingga mampu mewujudkan dalam kehidupan sehari-hari). KD (bersedia untuk berjuang menegakkan keadilan, kejujuran, kebenaran, perdamaian dan keutuhan ciptaan sesuai dengan kedudukan dalam masyarakat). Materi (menyebutkan kasus-kasus ketidakadilan yang terjadi dalam masyarakat).

Berdasarkan kriteria di atas, dalam pengembangan inovasi pembelajaran agama yang dilaksanakan didalam dan luar kelas (intrakurikuler dan ekstrakurikuler) tidak terlepas pada aspek kognitif, afektif, dan psikomotorik. Namun, ada kegiatan yang merupakan ketetapan dari pihak yayasan, sebelum melaksanakan prosesi pembelajaran yaitu melakukan ibadah (misa bersama (lagu dan doa) ini merupakan pembinaan rohani, pelaksanaannya dipimpin salah seorang guru bahkan peserta didik secara bergiliran setiap jam 07.00 (pagi) pada setiap hari persekolahan. Wujud dari kegiatan tersebut adalah untuk menciptakan dan membentuk kedisiplinan serta meyakini adanya Tuhan

Yohanes Arif Sanuri, adalah Waka kurikulum. Mengatakan bahwa, Ibadah bersama merupakan kewajiban yang harus dilaksanakan oleh warga sekolah. Sedangkan peserta didik yang beragama lain mengikuti ibadah bersama, hanya sebatas toleransi.

Adapun kalender pendidikan yang disusun berdasarkan kalender pendidikan Pendidikan Nasional yang dikombainkan dengan kalender pendidikan yang dikeluarkan oleh pihak yayasan. Guru hanya memasukkan jadwal yang telah diprogramkan, sehingga mudah menyesuaikan dalam penyusunan kalender pendidikan terkhusus pada materi pendidikan agama.

Menurut Adrianus Howy Rumene. Guru
Agama Yayasan. Buku-buku yang digunakan dalam pembelajaran pendidikan agama Katolik bersumber dari Bimas Katolik Kementerian Agama dan Konfrensi Wali Gereja Indonesia (KWI) di antaranya: Menjadi Murid Yesus, Persekutuan Murid-murid Yesus. Materi tersebut diajarkan tidak hanya pada proses belajar mengajar setiap hari, tetapi juga dituangkan pada bahan ujian semester dengan alasan, agar peserta didik non-Katolik dapat mengetahui pengetahuan perbandingan agama, kata lain hanya pada tataran kognitif.

Menurut Benjamin S. Bloom dkk, mengelompokkan tujuan pendidikan harus senantiasa mengacu kepada tiga jenis domain yang melekat pada diri peserta didik, yaitu: pertama, ranah proses berpikir (kognitif), kedua, ranah nilai/ sikap (afektif), dan ketiga, ranah keterampilan (psikomotor).

Dalam konteks evaluasi hasil belajar, maka tiga ranah (domain) yang harus dijadikan sasaran dalam setiap kegiatan evaluasi hasil belajar. Ranah kognitif adalah ranah yang mencakup kegiatan mental (otak), ranah afektif adalah tampak pada tingkah laku, sedangkan ranah psikomotor adalah ranah yang berkaitan dengan keterampilan (Anas Sudijono, 2008:49-57).

Menurut Ketsia adalah salah satu guru PNS yang dimanahkan oleh Kementerian Agama Provinsi Sulawesi Utara untuk mengajar pada lembaga pendidikan YPK. KM SMA Katolik St. Thomas Aquino dengan mengampuh mata pelajaran pendidikan agama dan pihak yayasan/ sekolah mempercayakan untuk mengajar bidang studi bahasa Indonesia. Kebiasaan peserta didik berdoa dengan menggunakan dua bahasa, yaitu Indonesia dan Inggris.

Dari hasil pengamatan, proses belajar mengajar pendidikan agama di kelas XI pada jam terakhir dengan KKM.KD Keterlibatan Gereja dalam Membangun Dunia Yang Damai dan Sejahterah, sedangkan materinya Memperjuangkan masyarakat yang adil damai dan sejahterah. Peserta didik menerima materi tersebut yang dituangkan lewat slide dan manual, kemudian dilanjukan dengan diskusi. Untuk mengukur dan mengevaluasi tingkat kompetensi peserta didik yaitu melihat sikap dan perilaku dalam menanggapi materi.

Secara garis besar pembelajaran pendidikan agama yang didapatkan para peserta didik yang beragama lain, hanya sebatas pada rana kognitif saja. Ini dibuktikan dari hasil ujian semester Marsel Reca Arianto Goni (siswa) yang beragama Islam, dengan nilai yang didapatkan masuk kategori sangat baik 
(100) dibandingkan dengan siswa yang beragama Katolik.

Dalam pelaksanaan kegiatan pembelajaran agama mengacu pada jadwal yang telah disusun pada kegiatan belajar mengajar (KBM), sehingga dapat mengantisipasi apabila ada guru yang berhalangan (inpal), pada intinya tinggal menyesuaikan. Adapun kegiatan bimbingan dan penyuluhan keagamaan terhadap peserta didik berupa ceramah yang terkait dengan sejarah tokoh agama dan masalah kenakalan remaja.

Menurut Jenny seorang pengawas/ penyelenggara Bimas Katolik Kementerian Agama Kota Manado, yang mengawasi beberapa Sekolah Katolik. Secara umum para guru dalam melaksanakan kegiatan belajar mengajar pada masing-masing bidang yang diampuh menekankan pada kedisiplinan, begitupun dengan materi tidak hanya bersumber pada buku saja, tetapi memanfaatkan teknologi (internet) yang dijadikan sebagai bahan ajar. Namun, tidak keluar dari substansi materi yang telah ditetapkan oleh Diknas, Kemenag dan YPK.KM.

Kompetensi pendidik (guru) pendidikan agama baik PNS maupun Non-PNS, memiliki latar belakang pendidikan yang memadai untuk seorang pendidik yaitu: Magister (S2). Namun, disisi lain dalam mengembangkan inprofisasi memerlukan waktu yang panjang, karena semua harus disetujui oleh pihak sekolah dan yayasan, di antaranya: buku recording (penghubung), dari hasil pengalaman Ketsia penggunaan buku recording pada SMA Hasanuddin Kabupaten Gowa yang diperuntukkan bagi peserta didik meghasilkan nilai positif.

Pelaksanaan evaluasi dari hasil kegiatan bimbingan, agar peserta didik dapat memahami tentang aturan yang diterapkan oleh pihak sekolah. Salah satu contoh: Saat siswa melanggar aturan tidak boleh membawa HP, maka guru agama langsung memberikan sangsi dengan memeriksa isi HP tersebut guna mengantisipasi apabila terdapat data-data terlarang. Akibat dari hal tersebut dapat merugikan siswa itu sendiri dan bahkan mempengaruhi citra sekolah itu sendiri.

Secara keseluruhan dalam mengevaluasi tingkat kemampuan siswa dalam pencapaian selama melangsungkan pendidikan (kelas X, XI, XII) diakumulasi berdasarkan pengetahuan, sikap, dan keterampilan yang dituangkan dalam bentuk rapor. Saat penerimaan rapor diwajibkan untuk menghadirkan orang tua/wali, karena momen ini merupakan hal yang sangat penting antara orang tua siswa dengan pihak sekolah. Strategi ini dilakukan pihak sekolah, guna menciptakan pendidikan karakter serta mewujudkan sinergisitas dalam membangun dan mengembangkan pendidikan di lembaga pendidikan formal SMA Katolik St. Thomas Aquino.

Pemberian nilai secara pluralistik pada semua materi pendidikan agama maupun umum, di antaranya: Manusia sebagai citra Allah. Dalam menggambarkan materi tersebut, ditekankan pada masalah keteladanan dan cara berperilaku yang baik terhadap sesama manusia, hal semacam ini merupakan aturan dan perintah pada semua agama. Sehingga peserta didik mampu mengaplikasikan dalam sehari-hari, baik disekolah, keluarga, maupun ditengah-tengah masyarakat.

Sedangkan dalam pencapaian ketuntasan belajar, peserta didik saat menghadapi mid semester maupun ujian semua guru mata pelajaran memberikan tugas disekolah maupun dirumah dalam format isian selama dua minggu, agar peserta didik dapat mempersiapkan diri untuk berkompetensi dan mampu menyelesaikan soal-soal yang dihadapi saat mengikuti mid semester dan ujian. Ada beberapa aspek yang dijadikan sebagai bahan penilaian terhadap peserta didik dalam pendidikan agama katolik, yaitu: kognitif (dituangkan lewat tugas-tugas harian, ulangan, dan semester dengan SKM 75, afektif (86-100), dan psikomotorik, di antaranya: melihat kemapuan peserta didik dalam aspek pengetahuan dan pemahaman lewat hafalan, melihat kemampuan cara bersikap sopan santun dan berprilaku yang baik sesama teman serta menggunakan busana sekolah yang sewajarnya, dan mampu mengimplementasikan ibadah secara berkesinambungan atau berkelanjutan.

Seperti yang telah dikemukaan St. Bernadette Mokorimban, Jmj (Sekertaris YPK.KM), bahwa semua peserta didik kelas XII diharuskan mengikuti retret, sedangkan guru agama memberikan tugas peserta didik kelas XII untuk membuat rosario (kalung/tasbi) dan kartu natal. Fungsi rosario digunakan saat beribadah (doa) dan diperuntukkan bagi semua guru mata pelajaran saat penerimaan rapor dan ijazah lewat undian yang dilakukan oleh peserta didik.

Strategi guru agama dalam meningkatkan motivasi dan semangat peserta didik dan orang tua siswa dalam mengembangkan pendidikan agama lewat kegiatan praktek disekolah divisualkan lalu diperlihatkan kepada orang tua siswa sebagai pembuktian bahwa mereka memiliki anak yang memiliki kemampuan secara psikomotorik. 
Menurut Jackson Sout (Waka kesiswaan), untuk menciptakan dan mewujudkan peserta didik bisa menjadi pintar dan cerdas atau sebaliknya, tidak terlepas dari kompetensi yang dimiliki oleh tenaga pendidik (guru) dalam memberikan pelatihan, pengajaran, dan pembinaan, karena ini merupakan hal penting untuk diketahui seorang pendidik baik informal, formal, maupun non-formal harus memahami ketiga aspek tersebut. Sehingga untuk mewujudkan keberhasilan dalam proses pembelajaran harus mampu mencintai secara utuh.

Keberhasilan dalam pengembangan pendidikan di sekolah SMA St. Thomas Aquino, tidak terlepas dari komponen pendidikan, begitupun secara operasional pihak lembaga pendidikan formal (sekolah) selalu berkoordinasi dengan pihak yayasan baik secara administrasi maupun secara tehnis terhadap semua lembaga pendidikan dibawah binaan yayasan keagamaan keuskupan, karena ini merupakan satu kesatuan yang telah ditetapkan lewat konferensi wali gereja Indonesia (KWI) yang dituangkan kedalam visi dan misi serta tujuan organisasi.

\section{Pendukung dan Penghambat}

Komponen dasar pendidikan adalah pengelolaan komponen-komponen yang mutlak harus ada dalam proses pendidikan, bila salah satu tidak ada maka proses pembelajaran tidak akan berjalan dengan normal bahkan bisa mengalami kegagalan apabila pihak sekolah tidak melihat manajemen kurikulum, kesiswaan, sarana dan prasarana, keuangan, tenaga pendidik dan kependidikan, hubungan masyarakat dan layanan khusus (Imam Wahyudi, 2012: 90-91).

Faktor pendukung, YPK.KM SMA Katolik St. Thomas Aquino berdomisili di daerah perkotaan, sehingga mudah dijangkau transportasi. Pemerintah daerah dan pemerintah (Diknas dan Kemenag) serta yayasan secara operasional bertanggung jawab dalam pembangunan dan perizinan YPK. KM. SMA Katolik ST. Thomas Aquino. Sehingga penyelenggaraan pendidikan masih berlangsung sampai sekarang tanpa ada intervensi dari luar.

SMA Katolik St. Thomas Aquino merupakan salah satu sekolah unggulan di Sulawesi Utara, para tenaga pendidik memiliki latar belakang pendidikan rata-rata sarjana yang memiliki kompetensi yang bervariatif berdasarkan mata pelajaran yang diampuh, dan tenaga kependidikan adalah orang yayasan. Kurikulum dan silabus yang dijadikan sebagai acuan/pedoman pembelajaran pendidikan agama bersumber dari pemerintah (Diknas/ Kemenag) dan yayasan yang dikombainkan ke dalam RPP. Walaupun sekolah Katolik, tetapi tidak mengurangi minat orang tua untuk menyekolahkan anaknya, ini dibuktikan secara kuantitas peserta didik yang beragama protestan lebih banyak dibandingkan agama katolik dan agama lain.

Pihak yayasan dan sekolah melakukan komunikasi dan koordinasi secara berkesinambungan dalam membangun kerukunan dan keharmonisan terhadap warga sekolah begitupun dengan pihak pemerintah, orang tua dan masyarakat dalam melangsungkan kegiatan pendidikan baik internal maupun eksternal.

Faktor penghambat, Pihak yayasan dan sekolah hanya merekrut guru agama Katolik, para pendidik (guru) memiliki keterbatasan dalam berinprofisasi, sebahagian orang tua dan masyarakat menyekolahkan anaknya tidak melihat pada aspek religinya, tetapi bagaimana bisa meneruskan pendidikan pada jenjang selanjutnya.

Implementasi pembelajaran pendidikan agama dan pendidikan keagamaan terfokus hanya pada pendidikan agama Katolik saja, sehingga untuk mengevaluasi tingkat kompetensi peserta didik yang beragama lain hanya pada ranah kognitif yang dijadikan sebagai bahan penilaian serta sebahagian orang tua belum tanggap terhadap bagaimana pentingnya peranan pendidikan agama dalam kehidupan sehari-hari.

Dalam proses kegiatan belajar mengajar mengacu pada visi dan misi serta tujuan organisasi, kemudian orang tua/masyarakat menyepakati aturan yang dikeluarkan pihak sekolah dan yayasan, tentang pendidikan agama yang harus dipelajari.

\section{PENUTUP}

Berdasarkan dari hasil uraian di atas, maka peneliti menyimpulkan sebagai berikut:

Secara kuantitas jumlah peserta didik yang mengenyam pendidikan di YPK.KM. SMA Katolik St. Thomas Aquino dominan beragama Protestan dibanding yang beragama Katolik dan agama lain. Sedangkan penerapan pembelajaran pendidikan agama Katolik diimplementasikan secara integrasi kepada peserta didik (multireligius).

Rencana Pelaksanaan Pembelajaran (RPP) pendidikan agama mengacu pada silabus Diknas/ Kemenag dan Yayasan yang dikombainkan ke dalam mata pelajaran. Sehingga untuk mengembangkan inovasi pada proses pembelajaran (intrakurikuler dan ekstrakurikuler) para tenaga pendidik (guru) tinggal menyesuaikan, tergantung pada bahan ajar/ 
materi yang disampaikan. Karena, pengembangan inovasi yang dilakukan dalam pembelajaran pendidikan agama harus sejalan dengan visi dan misi serta tujuan organisasi.

Faktor pendukung; secara operasional pemerintah daerah dan pemerintah (Kementerian Agama dan Kementerian Pendidikan Nasional), orang tua dan masyarakat merespon secara positif terhadap penyelenggaraan pendidikan pada sekolah YPK.KM SMA Katolik St. Thomas Aquino. Ini diperkuat lewat pernyataan yang disepakati oleh orang tua/masyarakat dengan pihak lembaga pendidikan formal (sekolah), sedangkan faktor penghambat; implementasi pembelajaran pendidikan agama dan pendidikan keagamaan terfokus hanya pada pendidikan agama Katolik saja, sehingga untuk mengevaluasi tingkat kompetensi peserta didik yang beragama lain hanya pada tataran kognitif yang dijadikan sebagai bahan penilaian dan sebahagian orang tua belum tanggap terhadap, bagaimana pentingnya peranan pendidikan agama dalam kehidupan sehari-hari.

\section{UCAPAN TERIMA KASIH}

Penelitian ini dibiayai oleh DIPA Litbang Agama Makassar Tahun 2014. Ucapan terima kasih diperuntukkan kepada para informan dilapangan khususnya para responden, juga terima kasih kepada teman-teman peneliti terkhusus bidang pendidikan agama dan keagamaan pada Balai Penelitian dan Pengembangan Agama Makassar atas kebersamaan kita selama ini.

\section{DAFTAR PUSTAKA}

Agung, Iskandar. 2012. Strategi Pengembangan Organisasi Pembelajaran di Sekolah. Jakarta: Bee Media Indonesia.

Ahmadi, Abu. 2001. Psikologi Sosial. Jakarta: Rineka Cipta.

Ancok, Djamaluddin. 2012. Psikologi Kepemimpinan Dan Inovasi. Jakarta: Erlangga.

Christensen, Clayton M. and Michael E Raymor. 2006. Solusi Sang Inovator. Jakarta: Serambi Ilmu Semesta.

Darmawan, Deni. 2012. Inovasi Pendidikan. Bandung: Remaja Rosda Karya.

Allitan, Lena dan Lina Anatan. 2009. Manajemen Inovasi- Tramnsformasi Menuju Organisasi Kelas Dunia. Bandung: Alfabeta.
Hamalik, Oemar. 2013. Kurikulum Dan Pembelajaran. Jakarta: Bumi Aksara.

Listia, dkk,. 2007. Problematika Pendidikan Agama Di Sekolah dalam Hasil Penelitian tentang Pendidikan Agama di Kota Yogyakarta 20042006. Yogyakarta: Intefdei.

Mudzhar, Atho, Marwan Sridjo ed. 2009. Mereka Bicara Pendidikan Islam Sebuah Bunga Rampai. Jakarta: Raja Grafindo Persada.

Peraturan Menteri Pendidikan Nasional Nomor 19 tahun 2007 Tentang Standar Pengelolaan Pendidikan.

Peraturan Menteri Pendidikan Nasional Nomor 28 tahun 2010 Tentang Penugasan Guru Sebagai Kepala Sekolah/Madrasah.

Peraturan Menteri Pendidikan Nasional Nomor 55 tahun 2007 Tentang Pendidikan Agama Dan Pendidikan Keagamaan.

Purwanto, Ngalim. 2000. Ilmu Pendidikan Teoritis Dan Praktis. Bandung: Remaja Rosda Karya.

Sudijono, Anas. 2008. PengantarEvaluasi Pendidikan. Jakarta: PT. Raja Grafindo Persada.

Sugiono. 2013. Metode Penelitian Kualitatif, Kuantitatif, Dan Kombinasi (Mixed Method). Bandung: Alfabeta.

Supranto, J. 2001. Pengukuran Tingkat Kepuasan Pelanggan. Jakarta: Rineka Cipta.

Trianto. 2013. Mendesain Model Pembelajaran Inovatif-Progresif. Jakarta: Kencana Prenada Media Group.

Undang-Undang Nomor 20 Tahun 2003 Tentang Sistem Pendidikan Nasional

Wahab, 2010. Laporan Penelitian Pelaksanaan Pendidikan Agama Pada Sekolah Swasta di bawah Yayasan Keagamaan. Semarang: Balai Litbang Agama Semarang.

Wahyudi, Iman. 2012. Pengembangan Pendidikan (Strategi Inovatif dan Kreatif Dalam Mengelola Pendidikan Secara Komprehensif). Jakarta: Prestasi Pustakaraya.

Sanjaya, Wina. 2009. Kurikulum Dan Pembelajaran. Jakarta: Kencana Prenada Media Group.

Zazin, Nur. 2012. Gerakan Menata Mutu PendidikanTeori Dan Aplikasi. Yogyakarta: Ar-Ruzz Media. 